\title{
Influence of additives on phase stabilization of scandia-doped zirconia
}

\author{
Eliana Navarro dos Santos Muccillo ${ }^{1}$, Robson Lopes Grosso ${ }^{1}$ \\ Shirley Leite dos Reis ${ }^{1}$, Reginaldo Muccillo ${ }^{1}$
}

\footnotetext{
${ }^{1}$ Energy and Nuclear Research Institute - IPEN - PO Box 11049 - 05422-970, S. Paulo, SP e-mail: enavarro@usp.br; roblopeg@usp.br; shirley.reis@usp.br; muccillo@usp.br
}

\begin{abstract}
The effects of small additions of tin, zinc, calcium and boron oxides on phase composition and electrical conductivity of zirconia-10 mol\% scandia were investigated. Compounds containing $1 \mathrm{~mol} \%$ zinc, tin and calcium oxides and 1, 3 and 5 wt.\% boron oxide were prepared by solid state reaction and characterized by X-ray diffraction, density measurements, scanning electron microscopy and impedance spectroscopy. Full stabilization of the cubic structure at room temperature was obtained with additions of $1 \mathrm{~mol} \%$ calcium oxide and 2 wt.\% boron oxide. Partially stabilized compounds exhibit herringbone structure, characteristic of the $\beta$ -

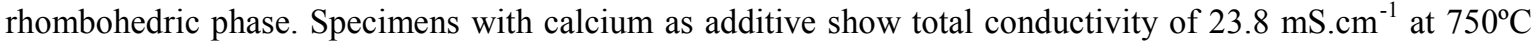
with activation energy of $1.13 \mathrm{eV}$. Liquid phase sintering by boron oxide addition is effective to enhance the densification of the solid electrolyte.
\end{abstract}

Keywords: scandia-doped zirconia, phase stabilizer, sintering aid, ionic conductivity.

\section{INTRODUCTION}

The combination of high ionic conductivity, wide electrolytic domain and low electronic conductivity turns the scandia stabilized zirconia, ScSZ, solid electrolyte a promising candidate for replacing yttria stabilized zirconia for application in solid oxide fuel cells operating at intermediate temperatures, typically $800^{\circ} \mathrm{C}[1-3]$. The higher ionic conductivity of ScSZ is found for scandia contents of 8-10 mol\% [3]. Nevertheless, the phase diagram of this solid electrolyte reveals a thermal degradation of the cubic phase for scandia contents up to $9-10 \mathrm{~mol} \%$ giving rise to the tetragonal polymorph. Moreover, for higher scandium contents, the cubic to $\beta$-rhombohedric phase transition readily occurs. Both, tetragonal and rhombohedric phases exhibit lower ionic conductivity than that of the high symmetry cubic structure $[2,3]$.

Then, up to date, one of the main goals has been to stabilize the cubic phase at room temperature. One approach to accomplish that is by the introduction of a second additive. In this context, continuing efforts have been made to find a suitable additive allowing for phase stabilization without excessive deterioration of the ionic conductivity. The additives investigated include those oxides with relatively high solubility such as rare earths [4-8] and other oxides [9-12].

So far, the higher ionic conductivity, amounting $\sim 18 \mathrm{mS} . \mathrm{cm}^{-1}$ at $600^{\circ} \mathrm{C}$, was found for the system zirconia-10 mol\% scandia-1 mol\% ceria [10]. However, it was found that the cubic phase transforms on the surface of the solid electrolyte to monoclinic via tetragonal phase during operation at $900^{\circ} \mathrm{C}$ of a tubular-type SOFC [13]. Conductivity degradation of this electrolyte was also observed at $600^{\circ} \mathrm{C}$ during long-term operation in humidified mixture of $\mathrm{H}_{2} / \mathrm{N}_{2}$ and humidified $\mathrm{H}_{2}$ [14].

In this work, small amounts of tin, zinc and calcium oxides as phase stabilizer, and boron oxide as sintering aid were added to zirconia-10 mol\% scandia and their effects on structure, microstructure and ionic conductivity were investigated.

\section{MATERIALS AND METHODS}

\subsection{Materials preparation}


Zirconia-10 mol\% scandia, ScSZ (Daiichi Kigenso Kagaku Kogyo, Japan), SnO (Alfa Aesar, 99.9\%), $\mathrm{CaCO}_{3}$ (Vetec, 99\%), zinc stearate $\left(\mathrm{Zn}\left(\mathrm{C}_{18} \mathrm{H}_{35} \mathrm{O}_{2}\right)_{2}\right)$ and boron oxide $\left(\mathrm{B}_{2} \mathrm{O}_{3}\right.$, Alfa Aesar 99.9\%) were the starting materials. The investigated composition was $\mathrm{ZrO}_{2}-10 \mathrm{~mol} \% \mathrm{Sc}_{2} \mathrm{O}_{3}-1 \mathrm{~mol} \% \mathrm{~A}(\mathrm{~A}=\mathrm{Zn}, \mathrm{Sn}, \mathrm{Ca})$ and 1,3 and 5 wt. $\% \mathrm{~B}_{2} \mathrm{O}_{3}$.

The starting materials were weighted in the stoichiometric proportion and mixed together in alcoholic medium followed by drying at $40^{\circ} \mathrm{C}$ for $1 \mathrm{~h}$. Cylindrical specimens were prepared by uniaxial $(50 \mathrm{MPa})$ followed by isostatic (100 MPa) pressing. The sintering of the green compacts was carried out at $1500^{\circ} \mathrm{C}$ for $5 \mathrm{~h}$ in a resistive furnace (Lindberg BlueM, 51524) with heating and cooling rates of 5 and $30^{\circ} \mathrm{C} \cdot \mathrm{min}^{-1}$, respectively. Specimens containing calcium and zinc were first heated up to $800^{\circ} \mathrm{C}$ for $1 \mathrm{~h}$ for precursor decomposition. Specimens with boron oxide addition were sintered at $1500^{\circ} \mathrm{C}$ for $4 \mathrm{~h}$. Sintered specimens are named 10Sc1ASZ standing for zirconia-10 mol\% scandia-x mol\% additive. The experimental procedure for boron oxide was similar to that of other additives. In this case the prepared compositions were zirconia-10 mol\% scandia-y wt. $\% \mathrm{~B}_{2} \mathrm{O}_{3}$ with $\mathrm{y}=1,2,3$ and 5 .

\subsection{Characterization methods}

The apparent density of sintered specimens was determined by measuring sample dimensions and mass and compared to the theoretical value calculated from the lattice parameters of the several compositions. Phase characterization was performed by room temperature X-ray diffraction, XRD (Bruker-AXS, D8 Advance) in the $20-80^{\circ} 2 \theta$ range with $\mathrm{Ni}$ filtered $\mathrm{Cu} \mathrm{K}$ radiation $(\lambda=1.5405 \AA$ ). Indexing of diffraction profiles was performed by comparison of XRD patterns with those of JCPDF 89-5483 and 511604 files for cubic and rhombohedric phases, respectively. The microstructure of sintered specimens was observed by field emission scanning electron microscopy, FEG-SEM (FEI, Inspect F50) on polished and thermally etched surfaces. The ionic conductivity was measured by two-probe electrochemical impedance spectroscopy (HP4192A), with $100 \mathrm{mV}$ of applied signal in the $13 \mathrm{MHz}-5 \mathrm{~Hz}$ frequency range. Silver and platinum were used as electrode materials for electrical measurements in the low $\left(<600^{\circ} \mathrm{C}\right)$ and high $\left(\geq 600^{\circ} \mathrm{C}\right)$ temperature ranges, respectively. Special software was used for data collecting and analysis [15].

\section{RESULTS AND DISCUSSION}

\subsection{Zirconia-10 mol\% scandia-1 $\mathrm{mol}^{2} \mathrm{SnO}_{2}, \mathrm{ZnO}$ and $\mathrm{CaO}$}

Figure 1a shows XRD patterns of zirconia-10 mol\% scandia-1 mol\% A $\left(\mathrm{A}=\mathrm{SnO}_{2}, \mathrm{ZnO}, \mathrm{CaO}\right)$ specimens sintered at $1500^{\circ} \mathrm{C}$ for $5 \mathrm{~h}$. Addition of calcium promoted fully stabilization of the cubic phase at room temperature. Specimens containing zinc oxide exhibit only reflections of the rhombohedric phase, whereas partial stabilization of the cubic structure is found for tin oxide addition. The angular region of $2 \theta$ between 48 and $53^{\circ}$ is highlighted in Fig. $1 \mathrm{~b}$ evidencing the phase composition for these specimens.
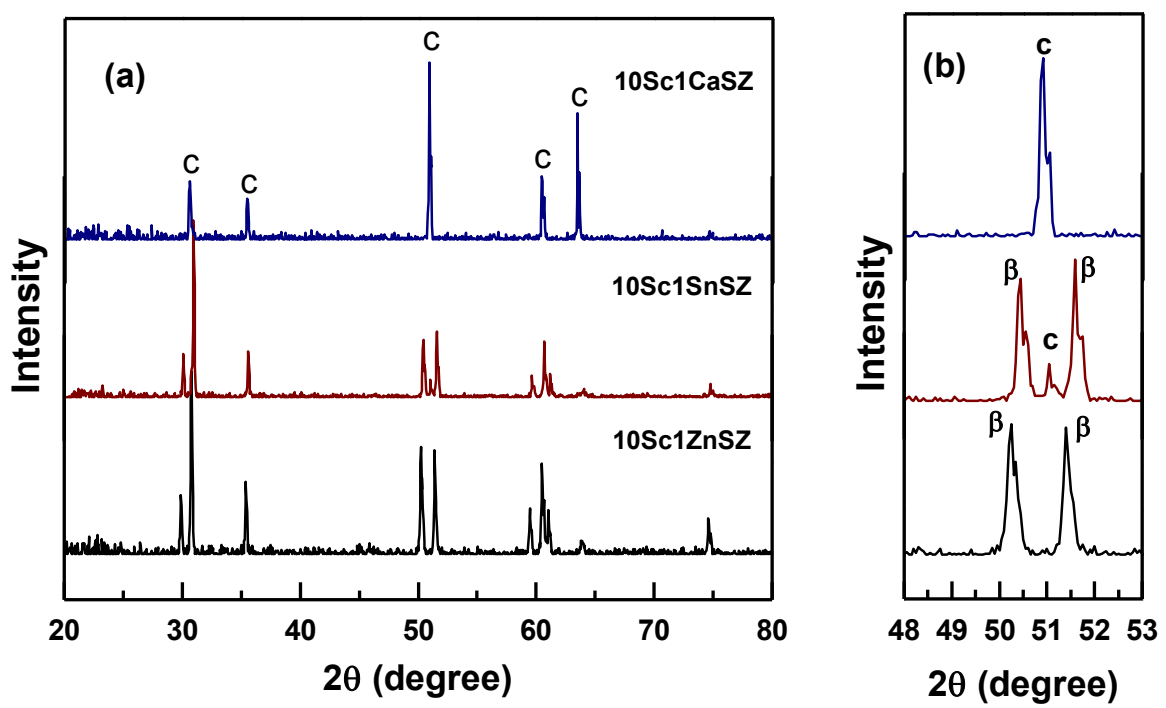

Figure 1: XRD patterns of $\mathrm{ZrO}_{2}: 10 \mathrm{~mol} \% \mathrm{Sc}_{2} \mathrm{O}_{3}-1 \mathrm{~mol} \% \mathrm{~A}\left(\mathrm{~A}=\mathrm{SnO}_{2}, \mathrm{ZnO}, \mathrm{CaO}\right)$ specimens sintered at $1500^{\circ} \mathrm{C}$ for $5 \mathrm{~h}$, 
in the (a) $20-80^{\circ}$ and (b) $48-53^{\circ} 2 \theta$ ranges; c and $\beta$ stand for the cubic and rhombohedric phases, respectively.

Table 1 lists values of relative density (in \%) and phase composition ( $c=$ cubic, $\beta=$ rhombohedric) of sintered specimens. It is remarkable the effect of the additive on microstructure. Zinc oxide does not promote phase stabilization and decreases the sintered density. Addition of calcium oxide is effective for the cubic phase stabilization at room temperature. Tin oxide promotes partial stabilization of the cubic phase with good densification.

Table 1: Values of relative density and phase composition ( $\mathrm{c}=$ cubic, $\beta=$ rhombohedric) of $10 \mathrm{Sc} 1 \mathrm{ASZ}(\mathrm{A}=\mathrm{Sn}, \mathrm{Zn}, \mathrm{Ca})$ sintered specimens.

\begin{tabular}{|c|c|c|c|}
\hline SPECIMEN & $\begin{array}{c}\text { RELATIVE DENSITY } \\
(\boldsymbol{\%})\end{array}$ & PHASE COMPOSITION & $\begin{array}{c}\text { MEAN GRAIN SIZE } \\
(\boldsymbol{\mu m})\end{array}$ \\
\hline $10 \mathrm{Sc} 1 \mathrm{SnSZ}$ & 97 & $\beta+\mathrm{c}$ & 10.0 \\
\hline $10 \mathrm{Sc} 1 \mathrm{ZnSZ}$ & 89 & $\beta$ & 11.4 \\
\hline $10 \mathrm{Sc} 1 \mathrm{CaSZ}$ & 97 & $\mathrm{C}$ & 12.5 \\
\hline
\end{tabular}

Figure 2 shows FEG-SEM micrographs of sintered specimens of $10 \mathrm{Sc} 1 \mathrm{ASZ}(\mathrm{A}=\mathrm{Sn}, \mathrm{Zn}$ and $\mathrm{Ca})$. The microstructure of sintered specimens consists of micrometer sized grains (Table 1). The herringbone structure, characteristic of the cubic-to-rhombohedric phase transition, is seem in the micrographs of specimens containing zinc and tin oxides, Figures $2 \mathrm{a}$ and $2 \mathrm{~b}$, respectively.

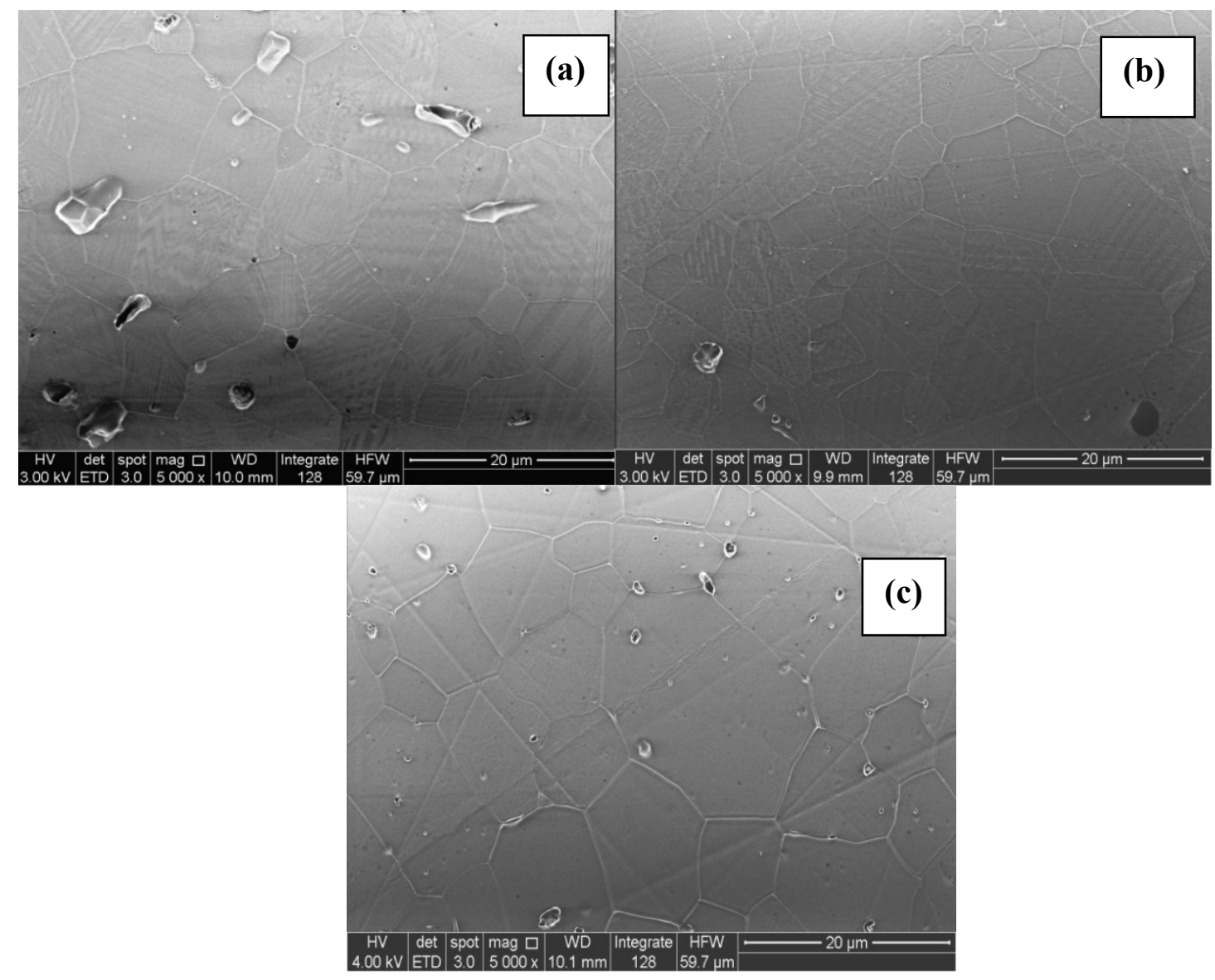

Figure 2: FEG-SEM micrographs of 10Sc1 ASZ. A: (a) Zn, (b) Sn, and (c) Ca.

These results indicate that calcium is a suitable phase stabilizer for zirconia-scandia electrolyte. Then, we investigated the electrical conductivity of this ternary system by impedance spectroscopy measurements. Figure 3 shows typical impedance diagram for $10 \mathrm{Sc} 1 \mathrm{CaSZ}$ collected at $400^{\circ} \mathrm{C}$, consisting of bulk (high frequency) and grain boundary (intermediate frequency) components of the electrolyte resistivity. In this figure, 
the original data was normalized for specimen dimensions. Then, the diameter of the high frequencies semicircle stands for the electric resistivity of the bulk (or grains), and that at intermediate frequencies the intergrain resistivity.

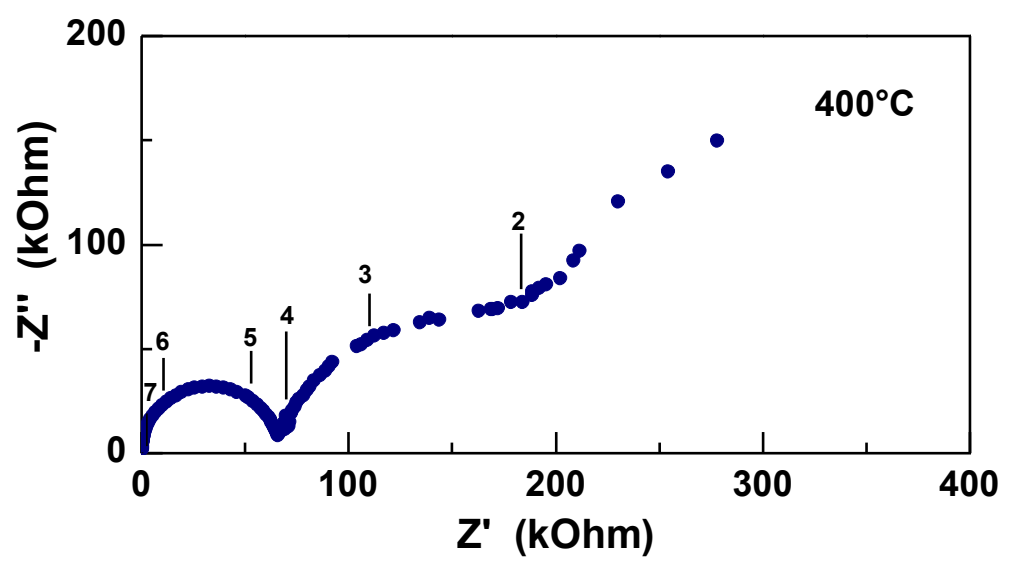

Figure 3: Impedance spectroscopy diagram of $10 \mathrm{Sc} 1 \mathrm{CaSZ}$ at $400^{\circ} \mathrm{C}$.

The Arrhenius plot of the total ionic conductivity of $10 \mathrm{Sc} 1 \mathrm{CaSZ}$ is shown in Figure 4 . In the low temperature range, the total conductivity $\sigma$ is higher than that of zirconia- $10 \mathrm{~mol} \%$ scandia, whereas the opposite trend is verified in the high temperature range. For example, at $600^{\circ} \mathrm{C}, \sigma$ amounts $3.8(10 \mathrm{Sc} 1 \mathrm{CaSZ})$ and 0.51 $(\mathrm{ScSZ}) \mathrm{mS} \mathrm{cm}^{-1}$, and at $750^{\circ} \mathrm{C}, \sigma$ is equal to $23.8(10 \mathrm{Sc} 1 \mathrm{CaSZ})$ and $37.9(\mathrm{ScSZ}){\mathrm{mS} . \mathrm{cm}^{-1}}^{-}$.

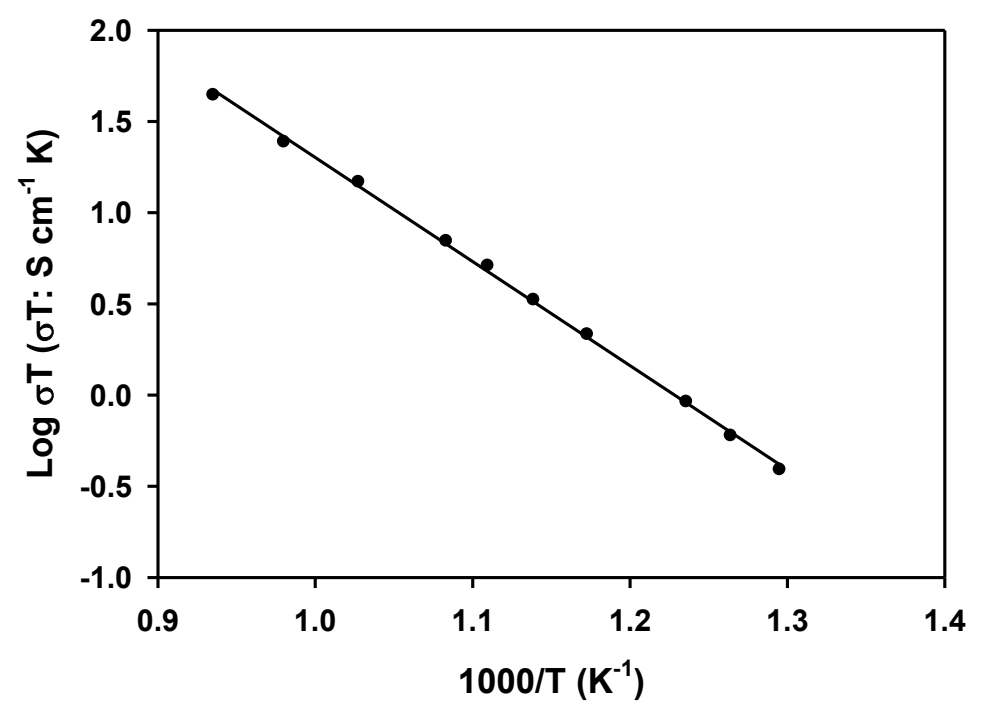

Figure 4: Arrhenius plots of total ionic conductivity of 10Sc1CaSZ.

In the whole temperature range of measurements, a single activation energy value for conduction was determined for $10 \mathrm{Sc} 1 \mathrm{CaSZ}, 1.13 \mathrm{eV}$.

\subsection{Zirconia-10 mol\% scandia-1-5 wt. $\% \mathrm{~B}_{2} \mathrm{O}_{3}$}

Figure 5 shows XRD patterns of zirconia-10 mol\% scandia-1 to $5 \mathrm{wt} \% \mathrm{~B}_{2} \mathrm{O}_{3}$ specimens sintered at $1500^{\circ} \mathrm{C}$ for $4 \mathrm{~h}$. Addition of $2 \mathrm{wt} . \%$ boron oxide promoted fully stabilization of the cubic phase at room temperature. 


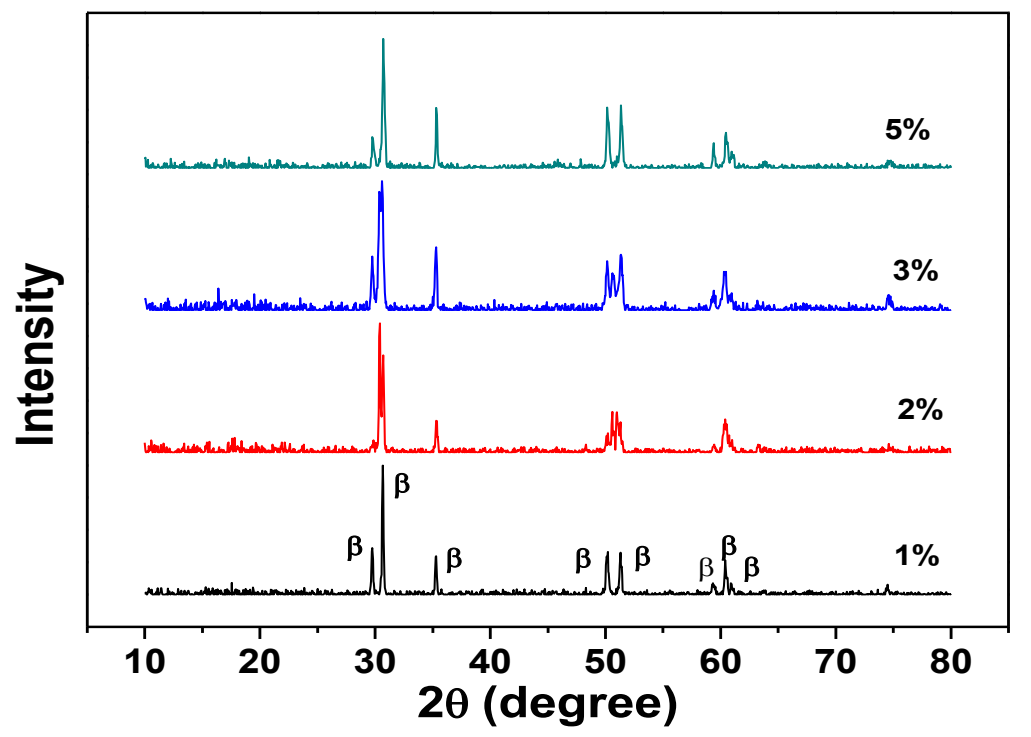

Figure 5: XRD patterns of $\mathrm{ZrO}_{2}: 10 \mathrm{~mol} \% \mathrm{Sc}_{2} \mathrm{O}_{3}-1$ to 5 wt. $\% \mathrm{~B}_{2} \mathrm{O}_{3}$ specimens sintered at $1500^{\circ} \mathrm{C}$ for $4 \mathrm{~h}$; $\beta$ stands for the rhombohedric phase.

Figure 6 shows FEG-SEM micrographs of sintered specimens of 10ScSZ sintered with addition of 1, 2, 3 and 5 wt. $\% \mathrm{~B}_{2} \mathrm{O}_{3}$. The microstructure of sintered specimens consists of micrometer sized grains. Boron oxide promoted densification via liquid phase sintering and porosity due to the capillary evolution of liquid boron oxide towards the pellet surface.

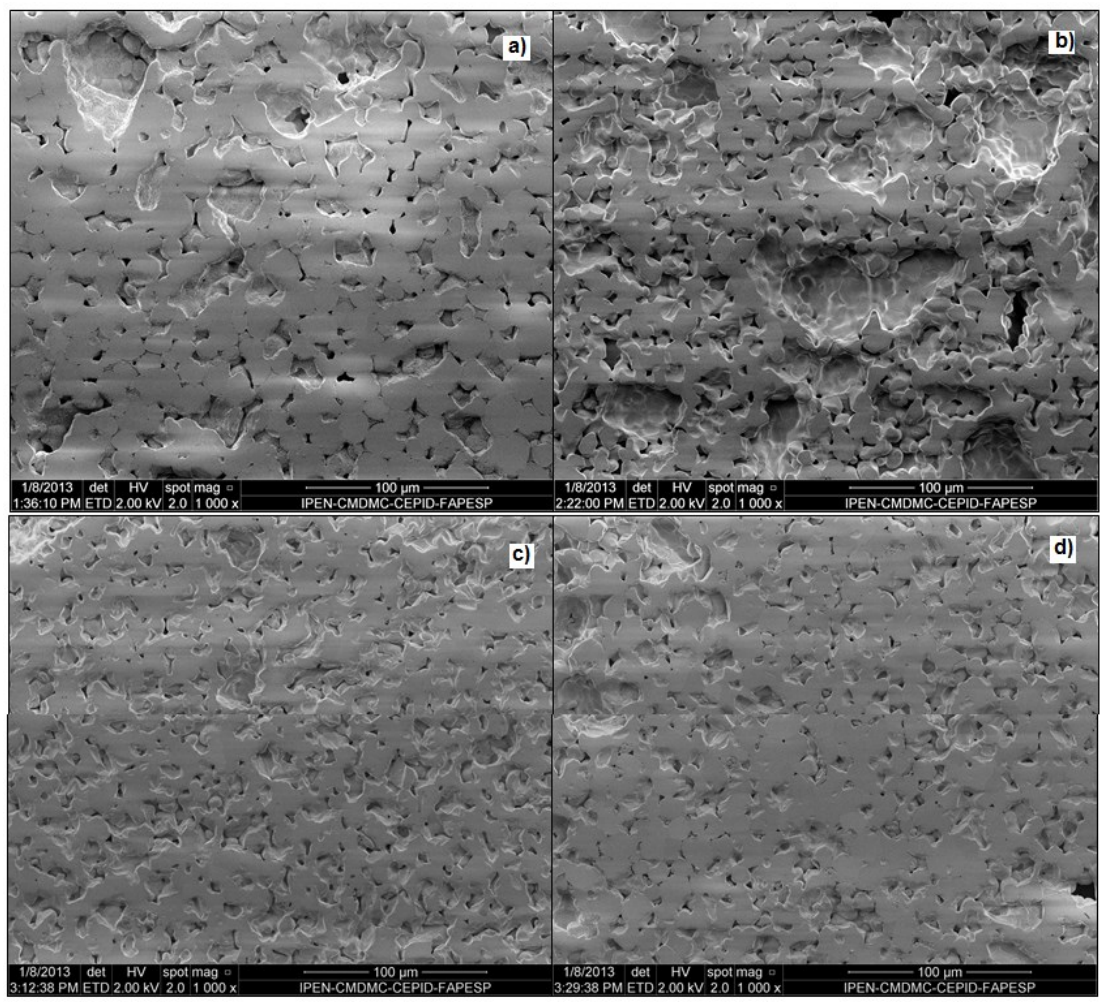

Figure 6: FEG-SEM micrographs of $10 \mathrm{ScSZ}+\mathrm{y}$ wt. $\% \mathrm{~B}_{2} \mathrm{O}_{3}, \mathrm{y}=1$ (a), 2 (b), 3 (c) e 5 (d), sintered at $1500^{\circ} \mathrm{C} / 4 \mathrm{~h}$.

Figure 7 shows impedance diagrams of specimens containing boron oxide measured at $420^{\circ} \mathrm{C}$ consisting of bulk and grain boundary components of the electrolyte resistivity. 

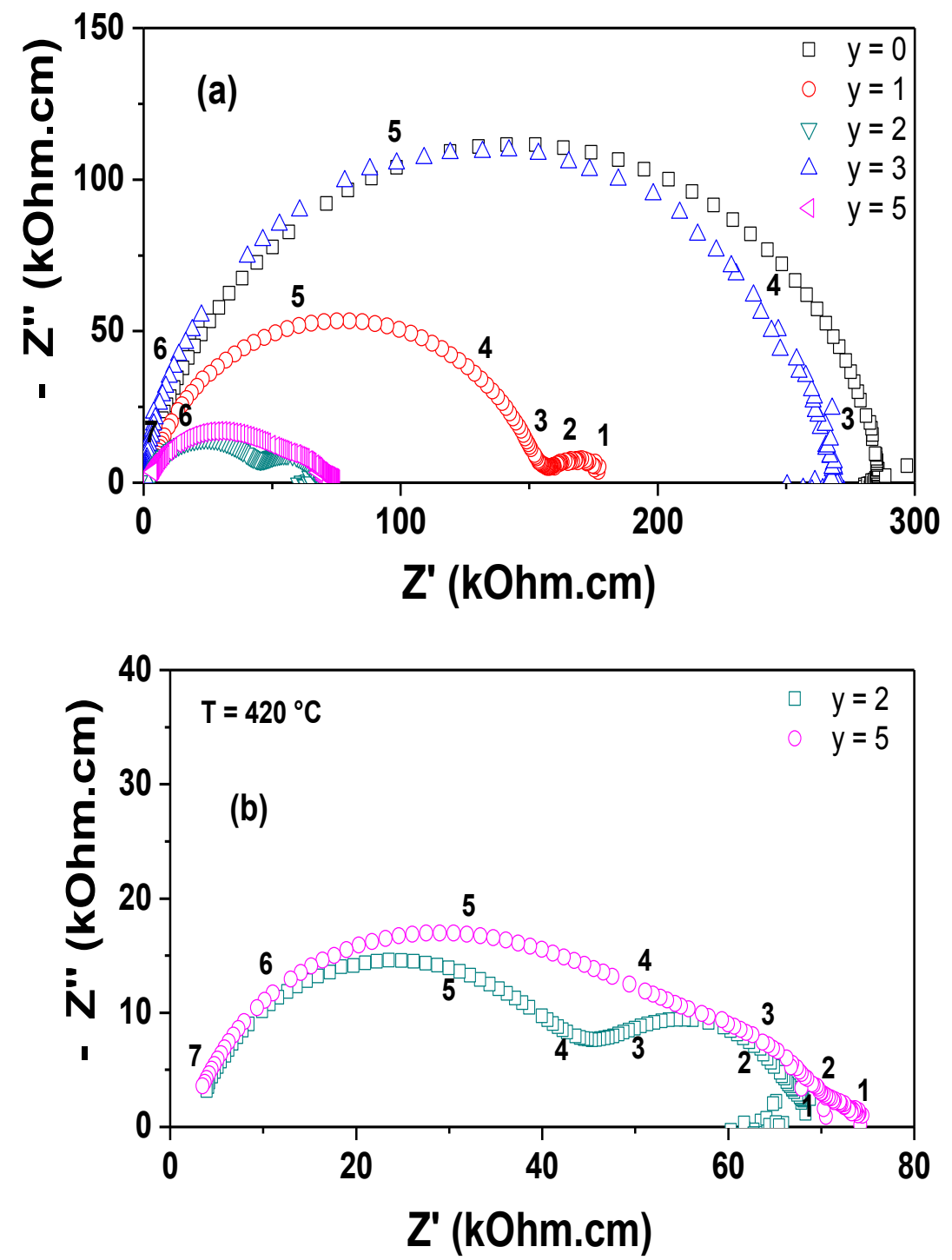

Figure 7: Impedance diagrams of $\left(\mathrm{ZrO}_{2}: 10 \mathrm{~mol} \% \mathrm{Sc}_{2} \mathrm{O}_{3}\right)+\mathrm{y}$ wt. $\% \mathrm{~B}_{2} \mathrm{O}_{3}\left(\mathrm{x}=0,1,2,3\right.$ and 5) sintered at $1500^{\circ} \mathrm{C} / 4 \mathrm{~h} ;(\mathrm{b})$ is a zoom of the $\mathrm{Z}^{\prime}<80 \mathrm{kOhm}$.cm region. Numbers stand for $\log \mathrm{f}(\mathrm{f}: \mathrm{Hz})$.

The addition of boron oxide leads to a decrease of the electrical resistivity of 10ScSZ. This might be due to the effect of liquid phase sintering, i.e., the wetting of the grain surfaces with enhanced densification. 2 wt. $\% \mathrm{~B}_{2} \mathrm{O}_{3}$ seems to be an optimum content to promote fairly dense specimens (Cf. Fig. 6) and enhanced ionic conductivity. Higher values of the additive (5 wt.\%) does not improve the ionic conductivity, probably by the occurrence of residual amorphous non conducting $\mathrm{B}_{2} \mathrm{O}_{3}$-related phases.

\section{CONCLUSIONS}

Scandia-stabilized zirconia, which has the higher oxide ion conductivity among the stabilized zirconias, was produced in single cubic phase or with partial stabilization of the cubic structure by adding aliovalent ions (Ca, Sn, $\mathrm{Zn}$ and B) prior to sintering. Improvement in the sintered density as well as in the ionic conductivity was achieved.

\section{ACKNOWLEDGEMENTS}

To FAPESP (2013/07296-2 and 2012/03319-5), CNEN, and CNPq (304073/2014-8) for financial support.

\section{BIBLIOGRAPHY}

[1] HAGENMULLER, P., VAN GOOL, W., Solid Electrolytes-general principles, characterization, materi- 
als, applications, New York, Academic Press, 1978.

[2] SUBBARAO, E. C., Solid Electrolytes and their applications, New York, Plenum, 1980.

[3] BADWAL, S. P. S., CHIACHI, F. T., MILOSEVIC, D., "Scandia-zirconia electrolytes for intermediate temperature solid oxide fuel cell operation”, Solid State Ionics, v. 136-137, PP. 91-99, 2000.

[4] YAMAMOTO, O., ARATI, Y., TAKEDA, Y., et al., "Electrical conductivity of stabilized zirconia with ytterbia and scandia", Solid State Ionics, v. 79, pp. 137-142, 1995.

[5] POLITOVA, T., I., IRVINE, J. T. D., "Investigation of scandia-yttria-zirconia system as an electrolyte material for intermediate temperature fuel cells-influence of yttria content in the $\left(\mathrm{Y}_{2} \mathrm{O}_{3}\right)_{\mathrm{x}}\left(\left(\mathrm{Sc}_{2} \mathrm{O}_{3}\right)_{(11-}\right.$ x) $\left(\mathrm{ZrO}_{2}\right)_{8.9}$, Solid State Ionics, v., 168, pp. 153-165, 2004.

[6] LEE, D.S., KIM, W. S., CHOI, S. H., et al., "Characterization of $\mathrm{ZrO}_{2}$ co-doped with $\mathrm{Sc}_{2} \mathrm{O}_{3}$ and $\mathrm{CeO}_{2}$ electrolyte for the application of intermediate temperature SOFCs", Solid State Ionics, v. 176, pp. 33-39, 2005.

[7] ABBAS, H. A., ARGIRUSIS, C., KILO, M., et al., "Preparation and conductivity of ternary scandiastabilised zirconia", Solid State Ionics, v. 184, pp. 6-9, 2011.

[8] GROSSO, R. L., MATOS, J. R., MUCCILLO, E. N. S., "Thermal and spectroscopic characterization of nanostructured zirconia-scandia-dysprosia”, J. Therm. Anal. Calorim., v. 117, pp. 567-572, 2014.

[9] VARANASI, C., JUNEJA, C., CHEN, C., et al., "Electrical conductivity enhancement in heterogeneously doped scandia-stabilised zirconia", J. Power Sources, v. 147, pp.128-135, 2005.

[10] OMAR, S., NAJIB, W. B., CHEN., et al., "Electrical conductivity of $10 \mathrm{~mol} \% \mathrm{Sc}_{2} \mathrm{O}_{3}-1 \mathrm{~mol} \% \mathrm{M}_{2} \mathrm{O}_{3}$ $\mathrm{ZrO}_{2}$ ceramics", J. Am. Ceram. Soc., v. 95, pp. 1965-1972, 2012.

[11] GROSSO, R. L., MUCCILLO, R., MUCCILLO, E. N. S., "Stabilization of the cubic phase in zirconiascandia by niobium oxide addition", Mater. Lett., v. 134, pp. 27-29, 2014.

[12] STANDAR, O. C., SORREL, C. C., "Densification of zirconia - conventional methods", Key Eng. Mater., v. 153-154, pp. 251-300, 1998.

[13] SHIMAZU, M., ISOBE, T., ANDO, S., et al., "Stability of $\mathrm{Sc}_{2} \mathrm{O}_{3}$ and $\mathrm{CeO}_{2}$ co-doped $\mathrm{ZrO}_{2}$ electrolyte during operation of solid oxide fuel cells", Solid State Ionics, v. 182, pp. 120-126, 2011.

[14] OMAR, S., BELDA, A., ESCARDINO, A., et al., "Ionic conductivity ageing investigation of 1Ce10ScSZ in different partial pressures of oxygen”, Solid State Ionics, v. 184, pp. 2-5, 2011.

[15] KLEITZ, M., KENNEDY, J. H., "Resolution of multi-components components impedance diagram", In: Vashishta, P., Mundy, J. N., Shenoy, G. K. (eds), Fast Ion Transport in Solids, Electrodes and Electrolytes, p.185-188, North-Holland, Amsterdam, 1979. 